\title{
ROBOT OPERÁCIÓS RENDSZER A „ROS 2.0” LEHETŐSÉGEINEK TÜKRÉBEN
}

\section{ROBOT OPERATING SYSTEM IN „ROS 2.0”}

\author{
Szögi Gábor \\ Óbudai Egyetem Bejczy Antal iRobottechnikai Központ, Cím: 1034, Magyarország, \\ Budapest, Bécsi út 96/B; Telefon: +36-1-6665700,,gabor.szogi@irob.uni-obuda.hu
}

\begin{abstract}
My research aims to provide insight into the robot operating system. It is presented, how it evolved to ROS and what has evolved over the years. ROS 2.0 in development will be presented during the system components, as well as the DDS system and its potential.

Keywords: ROS, robotics surveillance, industry 4.0

\section{Összefoglalás}

A kutatásom célja, hogy betekintést nyújtsak a robot operációs rendszerbe. Bemutatásra kerül, hogyan alakult ki a ROS, és milyen fejlődésen ment keresztül az évek során. A fejlesztés alatt lévő ROS 2.0 esetében bemutatásra kerülnek a rendszer alkotóelemei, valamint a DDS rendszer és a benne rejlö lehetőségek.
\end{abstract}

Kulcsszavak: ROS, robitka felügyelet, industry 4.0

\section{ROS története}

A Robot Operating System (ROS) egy nyílt forráskódú keretrendszer, amely saját könyvtár és eszközkészletével segítséget nyújt robot alkalmazások fejlesztésében. A meghajtókon keresztül a legkorszerübb algoritmusokon át egy erős fejlesztési eszköz, amely segítséget nyújthat robotikai projektek megvalósításában. A ROS egy flexibilis keretrendszer, amely robot szoftverek fejlesztéséhez került kialakításra. Az eszköztárak és könyvtárak gyüjteménye egyezményesen került kialakításra, amelynek célja, hogy egyszerüsítse a fejlesztést a különböző robot platformokon keresztül. Sokan érezték szükségét a nyílt végü együttmüködési rendszernek a robotikai kutatók körében és a cél elérése érdekében több projektet is indítottak. A 2000-es évek közepén a Stanford Egyetemen többek között a mesterséges intelligencia bevonásával két projektet indítottak. A STanford AI Robot (STAIR) és a Personal Robot $(\mathrm{PR})$ projekt egy házon belül készített prototípus, amely egy rugalmas és dinamikus szoftver rendszert foglalt magában robotikai használatra szánva. 2007-ben Willow Garage, amely egy robotikával foglalkozó inkubátorház, jelentős forrásokat biztosított a projektek számára, hogy biztosítsa a koncepció megvalósítását. Ezek az erőfeszítések felpezsdítettek számtalan kutatócsoportot, akik idöjükkel és szakértelmükkel hozzájárultak az alapvető szoftver csomagok kifejlesztéséhez, a ROS magjának megvalósításához. Az egész a szoftvert a nyílt forráskódú Berkeley Software Distribution (BSD) licence használatával fejlesztették és fokozatosan 
terjedt el a robotikai kutató közösség körében. A ROS-t a kezdetektől több intézmény közremüködésével különböző robotokhoz fejlesztették, többek között a (PR) fejlesztőit a Willow Garage-böl. A ROS ökoszisztéma egyik erőssége, hogy az évek során az az eljárás alakult ki, hogy a forráskódok mindenki számára elérhetőek. Bármely fejlesztő csoport létre tudja hozni és elérhetővé teheti saját ROS kód gyüjteményét a saját szerverén. Ha a fejlesztő csoport úgy dönt, hogy nyilvánosan elérhetőek a forráskódok, akkor nem kellenek engedélyek a használatához. Ebből eredően a ROS ökoszisztémában több tízezer felhasználó vesz részt a hobby projektektől a nagy ipari automatizálási rendszereken keresztül. [1,3]

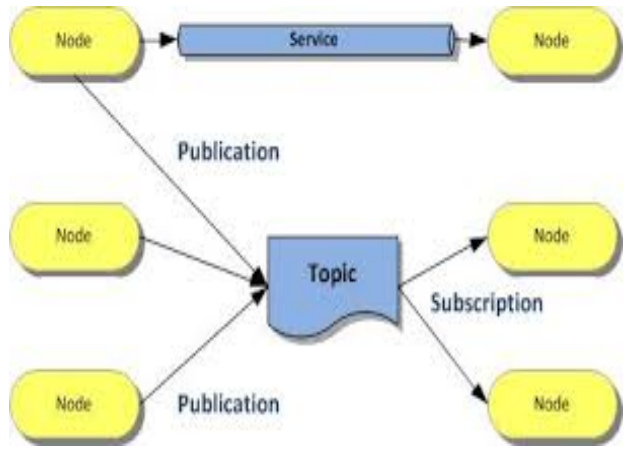

1. ábra. ROS felépitése

\section{ROS 2.0}

A projekt elindulásakor a fejlesztő közösség nem fektetett nagy hangsúlyt az alábbi felhasználói estekre, amelyek szükségessé tették a további fejlesztéseket:

- Több robot közös csoportokban: Bár a ROS lehetőségeset ad a multi robot rendszerek kialakítására, de nem alakult ki rá elfogadott szabvány, ezért könnyen hozzáférhetö és feltörhető a ROS singlemaster struktúrája.

- Kisméretü beágyazott rendszerek: Kisméretü számítógépek alkalmazása, beleértve a mikro kontrollereket, hogy első osztályú része lehessen a ROS környezetnek.

- Valós idejű rendszerek: Támogathatóvá válik a valós idejű irányítás közvetlenül a ROS-ban, beleértve az ,inter-process” és ,inter-machine” kommunikációt, amelyhez elengedhetetlen a megfelelö operációs rendszer és a megfelelö hardver támogatás.

- Nem ideális hálózatok: Fontos cél, hogy a ROS alkalmassá váljon, amennyire lehetséges a hálózati kapcsolat elvesztése nélkül a megfelelö kommunikációs kapcsolat fenntartásához.

- Termelési környezet: Létfontosságú, hogy a ROS egy választási lehetőség maradjon a kutatási területen, de biztosítani kell a ROS alapú laborotóriumi prototípusok fejlesztését, hogy a való életben alkalmasak legyenek további felhasználásra.

-Elöírt minták rendszerek építéséhez strukturáláshoz: A ROS-t a rugalmasság fémjelzi, miközben továbbra is fenntartja, hogy könnyen átlátható mintákat biztosít a fejlesztők számára.

A ROS magja egy anonim publishsubscribe middleware rendszerre épül szinte teljesen a nulláról építkezve. A fejlesztés időszakában amely 2007 óta tart, számos új technológia jelent meg, amelyek relevanciával bírnak a ROS 2.0 tekintetében az alábbi területeken:

- Zeroconf;

- Protocol Buffers;

- ZeroMQ

- Redis;

- WebSockets;

- DDS (Data Distribution Service).

Ma már lehetősége van ROS-szerü middleware rendszer építésére „off-theshelf” nyílt forráskódú könyvtárak segítségével. Rendkívül hasznosak lehetnek ebből a megközelítésből többek között az alábbiak: 
- Kevesebb kód kezelése, különösen a nem robotikai specifikus kódok tekintetében.

- Kihasználható funkciók azokban a könyvtárakban, amelyek kívül esnek azon, amit mi magunk készítettünk.

- Hasznos a folyamatos tökéletesítés terén, a mások által készített könyvtárak áttekintése és használata.

- Rámutathatunk a már meglévő termelő rendszerekre, amelyek a már meglévő könyvtárakra támaszkodhatnak. [2,3]

\section{ROS 2.0 a DDS-ben}

A cél, hogy elkészüljön a DDS a ROS 2.0 implementációs részleteivel. Ez azt jelenti, hogy az összes DDS specifikus APIt és üzenet definíciót el kellene rejteni. A DDS biztosítja a felfedezést, üzenet definíciót, üzenet sorba rendezést és a publis-subscribe szállítását.

\subsection{Mi a DDS?}

A DDS (Data Distribution Service) biztosítja a publish-subscribe szállítást, amely nagy mértékben hasonlít a ROS publish-subscribe szállitásához. A DDS az IDL (Interface Description Language) által meghatározott nyelvet használja, amely az OMG (Object Management Group) által lett kialakítva az üzenetek definiálására. és sorba rendezésére. A DDS-nek a „kérésválasz" stílusú szállítása olyan lenne, mint a ROS szolgáltató rendszere, amelyet DDSRPC-nek neveztek el.

Az alapértelmezett felfedező rendszer a DDS által biztosított, amely szükséges a DDS purblish-subscribe rendszer szállításához, amely egy elosztott felfedező rendszer. Ez lehetővé teszi bármely két DDS program közötti kommunikációt anélkül, hogy ROS master-re lenne szükség. Ez teszi a rendszert még hibatürőbbé és rugalmassá. Nem szükséges a dinamikus felfedező mechanizmusok használata, azonban a többszörös DDS gyártók lehetőséget biztosítanak a statikus felfedezésre. [4]

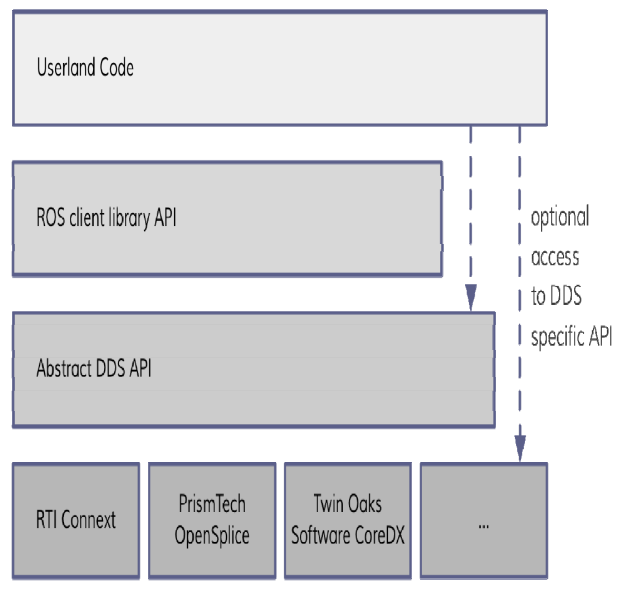

2. ábra. DDS és ROS API layout

\section{ROS 2.0 alkotó elemei}

Bár nem lehet biztosítani egy átfogó listát, hogy mit tartalmaz a ROS ökoszisztéma, ettől függetlenül azonosítani lehet az alapvető részeit, amelyek a funkcionalitás, müszaki elóírások és a minsőség érdekében hozzájárulhatnak a ROS projekthez. [1]

\subsection{Kommunikációs infrastruktúra}

A legalsó szinten a ROS egy üzenet passing interfészt kínál, amely a folyamatok közötti kommunikációt biztosítja, amit gyakran middleware-nek neveznek.

\subsection{Robotspecifikus jellemzők}

A fö middleware elemeken felül a ROS közös robot-specifikus könyvtárakat és eszközöket biztosít, amellyel könnyen és gyorsan tudunk robotot összeállítani és beállítani. Néhány robot specifikus képesség, amelyet a ROS biztosít:

Robot geometria könyvtár, robot leíró nyelv, diagnosztika, lokalizáció, térképezés, navigáció 


\subsection{Eszközök}

Az egyik legerősebb jellemzője a ROSnak az erős fejlesztési eszközkészlet. Ezek az eszközök támogatják az önelemzést, a hibakeresést, a plottingot és a vizualizációt. A rendszer alapjául szolgáló publissubscribe mechanizmus lehetővé teszi, hogy spontán módon elemezhetővé válnak a rendszerbe áramló adatok, így könnyebbé válik a hibaellenörzés. A ROS eszközök kihasználják az önvizsgálati képességeket, a kiterjedt grafikus könyvtárakat és a parancssoros segédprogramokat, így leegyszerüsödhet a fejlesztés és hibakeresés.

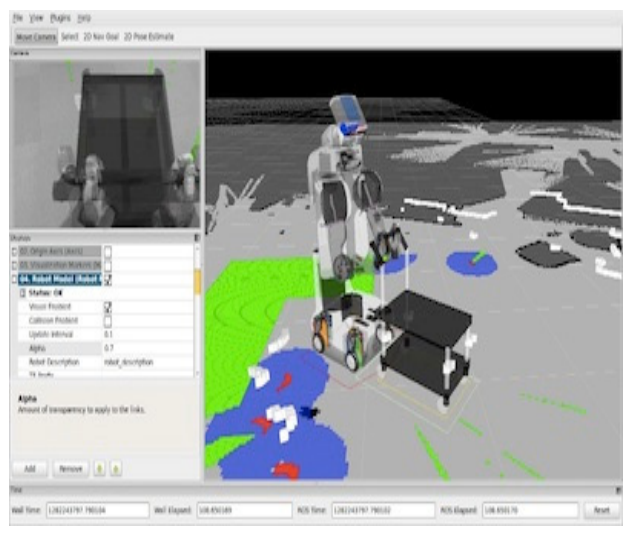

3. ábra. rviz layout

\section{Következtetések}

A kutatás eredményeként megállapítható, hogy a ROS egy hatalmas projekt, rengeteg közremüködő fejlesztő együttmüködésével.

Sokan érezték szükségét a nyílt végü együttmüködési rendszernek a robotikai kutatók körében és a cél elérése érdekében több projektet is indítottak. A ROS-t használva könnyü újra felhasználható kódot készíteni. Az ROS esetében több kisebb alkalmazás fut egyidejüleg - ezeket nodeoknak nevezzük, amelyek közül a legfontosabb node a 'roscore'. Ez a node biztosítja az alapvető funckiókat, és a nodeok kommunikációját. A különböző node-ok a 'roscore' node-t keresik fel, azáltal ismerik fel környezetüket Még mindig rengeteg kérdés merül fel a DDS hasznosítása esetében.

\section{Köszönetnyilvánítás}

Ezúton szeretnék köszönetet mondani az Óbudai Egyetem Robottechnikai Szakkollégium részére, amelynek tagjaként számos szakmai és anyagi támogatást kaptam jelen szakmai tudományos publikációm elvégzéséhez. A szakkollégium kiemelt segítséget nyújt az Óbudai Egyetem tehetséges hallgatóinak és doktoranduszainak.

\section{Szakirodalmi hivatkozások}

[1] http://www.ros.org/

[2] http://design.ros2.org/

[3] A. Koubaa, Robot Operating System (ROS): The Complete Reference. Springer, 2016.

[4] http://design.ros2.org/articles/ros on dds.ht $\underline{\mathrm{ml}}$ 